\title{
SELECTED ASPECTS OF THE MANAGEMENT OF REAL ESTATES OWNED BY LEGAL PERSONS OF CHURCHES AND OTHER RELIGIOUS ASSOCIATIONS
}

\author{
Agnieszka Cienciała \\ Faculty of Environmental, Geomatic and Energy Engineering \\ Kielce University of Technology \\ e-mail: acienciala@tu.kielce.pls
}

\begin{abstract}
At the end of 2012, there were 174 churches and religious associations operating in Poland (GUS 2014). Most of the individuals (nearly 96\%) are the followers of the Roman Catholic Church. The Catholic Church and its organizational units have legal personality, thereby enabling them to acquire, possess and dispose of the title to real estate and other property rights, and administer the properties. In the years 1944-1962, almost all ecclesiastical real estates were nationalized. The asset-related situation of church legal persons was regulated upon the entry into force of the Act of 17 May 1989 on the relations between the State and the Catholic Church in the Republic of Poland. In 1991-2004, the legislator also regulated the legal status of many other churches and religious associations. Moreover, a fairly uniform system of ecclesiastical reprivatization was developed.

For the purposes of the publication, analyses of selected aspects concerning the management of real estates owned by legal persons of churches and other religious associations in Poland have been carried out. Cases of the approaches adopted in other exemplary countries have also been presented. The intention is to indicate the rules in force as well as the problems encountered in this regard.
\end{abstract}

Key words: real estate management, ecclesiastical properties, nationalisation, reprivatisation.

JEL Classification: K11, R52.

Citation Cienciała A., 2019, Selected Aspects of the Management of Real Estates Owned by Legal Persons of Churches and Other Religious Associations, Real Estate Management and Valuation, vol. 27, no. 3, pp. 97108.

DOI: $10.2478 /$ remav-2019-0028

\section{Introduction}

Property management is defined as a complex, continuous and systematic process of analysis, planning, management and control of real estate portfolios designed to increase transparency for the property owner (or investor), to strike a balance between income and the risks of real estate investment and management decisions related to the property portfolio (MUCZYŃSKI et al. 2015). It constitutes a very important and dynamically changing field. The changes include technical, procedural and legal aspects, and result from an attempt to solve current problems in these fields throughout the world and in Poland (SOBOLEWSKA-MIKULSKA 2014). One of the more interesting issues in this regard, significant when we consider the scale of the phenomenon, is the management of real estates owned by legal persons of churches and other religious associations. Due to the multitude of regulations and principles in force, this subject is very extensive and cannot be described in detail within a single scientific publication. According to a report by the Central Statistical Office (GUS 2014), at the end of 2012, there were as many as 174 churches and religious associations operating in 
Poland. Fig. 1 presents the percentage share of followers of particular churches or religious associations in Poland. The vast majority of the individuals in the country (amounting to nearly 96\% of the population) are, however, the followers of the Roman Catholic Church [1], 0.44\% - of the Orthodox Church [2], 0.39\% - of the Religious Association of Jehovah's Witnesses [3], $0.20 \%$ - of the Evangelical Church of the Augsburg Confession [4], 0.09\% - of the Greek Catholic Church [5], 0.08\% of the Pentecostal Church [6], 0.03\% - of the Old Catholic Mariavite Church [7], 2,77\% - of other churches or religious associations [8].

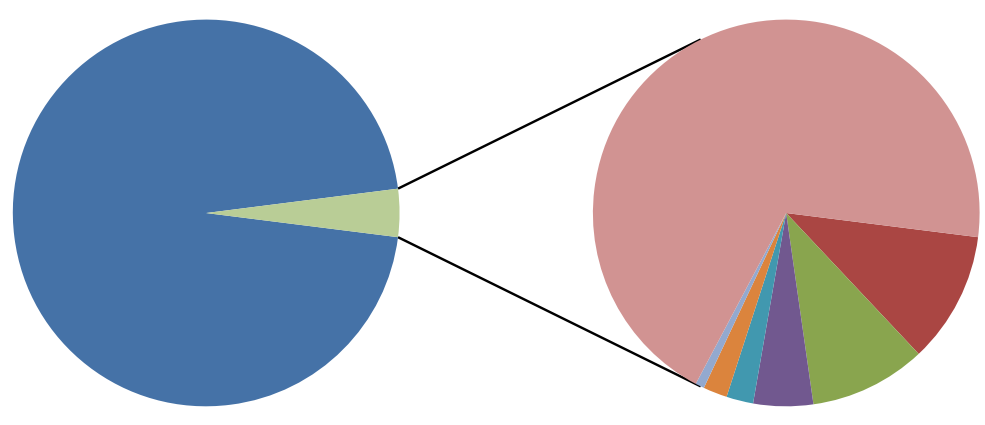

$\square 1-2 \quad 3 \quad 4 \quad 5 \quad 6 \quad 7 \quad 8$

Fig. 1. The followers of different church or religious associations in Poland. Source: work based on the data of the Central Statistical Office (GUS 2014).

The aim of the present publication is the analysis of selected aspects concerning the management of real estates owned by legal persons of churches and other religious associations in Poland and the indication of the approaches to the matter adopted in other exemplary countries of the world. The intention is to indicate the relevant applicable rules as well as specify the existing problems. As good governance is a very broad concept that accounts for various processes in land management and land administration (KLIMACH, DAWIDOWICZ, ŹRÓBEK 2018), the SWOT analysis was prepared for the selected methods of management to indicate their strengths, weaknesses, opportunities and threats.

\section{Literature review}

From a legal perspective, all the churches and religious associations can be divided into three groups: the first including those whose legal status is based on specially dedicated laws or the concordat (15 churches), the second comprises those registered according to the general rules of the applicable religious law, and the third is made up of ones which have not obtained a legal status for various reasons (GUS 2014). The legal status of Churches and religious associations as well as their assetrelated issues were regulated after 1989, under a series of laws [Table 1] in connection with the sociopolitical transformation taking place in Poland at the time and with the liberalization of religious law. For example, the asset-related situation of the Catholic Church was regulated upon the entry into force of the Act of 17 May 1989 on the relations between the State and the Catholic Church in the Republic of Poland. The situation of the Orthodox Church, on the other hand, was regulated under the Act of 4 July 1991 on the relations between the State and the Polish Autocephalous Orthodox Church, and in the years 1991-2004, separate laws were introduced to govern the legal status of a series of other churches and religious associations.

Table 1

Selected legal acts concerning the legal status of Churches and religious associations in Poland

$$
\text { Legal acts }
$$

Act of 23 June 1971 on the transition to legal entities of the Roman Catholic Church and other churches and religious associations of the ownership of certain properties located in the western and northern territories (Journal of Laws of 1971 No.16, item 156) 
Act of 17 May 1989 on the relation of the state to the Catholic Church in the Republic of Poland (Journal of Laws of 1989 No.29, item 154)

Act of 4 July 1991 on the relation of the State to relationship to the Polish Autocephalous Orthodox Church (Journal of Laws of 1991 No.66, item 287)

Act of 11 October 1991 amending the act on the relation of the State to the Catholic Church in the Republic of Poland (Journal of Laws of 1991 No.107, item 459)

Act of 13 May 1994 on the relation of the State to the Evangelical-Augsburg Church in the Republic of Poland (Journal of Laws of 1994 No. 73, item 323)

Act of 13 May 1994 on the attitude of the State to the Evangelical-Reformed church in the Republic of Poland (Journal of Laws of 1994 No.73, item 324)

Act of 30 June 1995 on the attitude of the State to the Evangelical-Methodist church in the Republic of Poland (Journal of Laws of 1995 No.97, item 479)

Act of 30 June 1995 on the relation of the State to the Baptist Church in the Republic of Poland (Journal of Laws of 1995 No.97, item 480)

Act of 30 June 1995 on the relationship of the State to the Seventh-day Adventist Church in the Republic of Poland (Journal of Laws of 1995 No.97, item 481).

Act of 30 June 1995 on the State's relationship with the Polish Catholic Church in the Republic of Poland (Journal of Laws of 1995 No.97, item 482).

Act of 20 February 1997 on the relation of the state to Jewish religious communities (Journal of Laws of 1997 No. 41, item 251)

Act of 20 February 1997 on the relationship States to the Mariawite Catholic Church in the Republic of Poland (Journal of Laws of 1997 No. 41, item 252)

Act of 20 February 1997 on the relation of the State to the Old Catholic Mariavite Church in the Republic of Poland (Journal of Laws of 1997 No. 41, item 253)

Act of 20 February 1997 on the relationship between the State and the Pentecostal Church in the Republic of Poland (Journal of Laws of 1997 No. 41, item 254) 
As indicated by KALETA (2017), the right of the Church to manage its temporal goods is its own right, arising out of an inherent right, and is independent from any secular power, with such goods being directed to a purpose befitting the Church's mission. A characteristic feature of church legal persons is that they are governed by two legal systems, namely the state and canonical. It must be emphasized that Churches use separate solutions concerning property management, which are specific to each of them and contain various levels of detail, with the overarching objective, however, being - as a rule - the protection of the goods possessed. As pointed out by BENDZA (2009), there are also differences in the approach of the executive and legislative powers with regard to sorting out the property issues of the Catholic Church and of minority churches, which was manifested, amongst others, in the application of different legal mechanisms with respect to the issues of repossession of real estates taken over by the State during the time of the People's Republic of Poland.

In the international arena, according to KALETA (2012), it is not possible to establish universal law even for the entire Catholic Church. This is because the subject in question is closely related to the specificity of the particular countries as well as to their economic conditions. To begin with, the legal definitions of land ownership vary between countries. Some countries do not have land ownership at all, others are based on Germanic or Roman law or on other legal traditions (PAASCH, PAULSSON et al. 2016). According to HEARING (2016), various models and systems of acquiring temporal goods have been developed to meet the needs of religious communities. The Author gives an example of Germany, where there is a wide range of possible forms of acquisition of goods by the Catholic in the country and considerable real estate assets have been developed over a long period of time. According to SLACK (2016), in Australia, archdioceses, dioceses, eparchies to the Latin dioceses, the military ordinariate and the ordinariate of the southern cross are regarded as unincorporated associations and, as such, they cannot own property, sue or be sued. Use must be made, therefore, of the instruments provided by civil law, in order to safeguard the ownership of temporal goods (SLACK 2016). In the United States, while the Church is free to establish dioceses, parishes and other ecclesiastical institutions and to govern these entities in accord with the norms of canon law, these groupies are, in American law, private, voluntary associations (BEAL 2016). The author says that, since property law in the United States is governed largely by the laws of the several states, the legal vehicles by which a private association can secure legal recognition of its ownership of property vary, sometimes widely, from one jurisdiction to another. Despite the differences in the legal regulations in force in a given country, there are similar objectives for the management of the properties owned by church legal persons, namely the preservation and protection thereof.

In Poland, the Catholic Church, as a whole as well as its organizational units, have juridical (legal) personality, which has been regulated under the Act of 17 May 1989 on the Guarantees of the Freedom of Conscience and Religion as well as the Act of 17 May 1989 on the relations between the State and the Catholic Church in the Republic of Poland. Within the meaning of the canon law, legal persons may include groups of natural persons, such as dioceses, parishes, personal prelatures, associations, or groups of objects, e.g. autonomous foundations. An organizational unit of the Church retains its legal personality upon its establishment under canon law, whereas the state law recognizes this personality and incorporates a given unit into the state law system (MALESA, WAWRZASZEK 2014). Pursuant to Article 52 of the Act of 17 May 1989 on the relations between the State and the Catholic Church in the People's Republic of Poland, the Church and its legal persons shall have the right to acquire, possess and dispose of movable and immovable properties, to acquire and dispose of other rights, as well as to manage their assets. Legal personality is also possessed by institutes, provinces and religious houses, and it is the superior who directly manages a given legal person, acting on their behalf in cases pertaining to property management. Within the structure of the Church, it is also possible to identify organizational units without legal personality (publishing houses, service providers, charitable care establishments, schools and other educational institutions, etc.).

\section{Data for the analyses and methods}

As it has been mentioned, the main subject of the research are selected aspects of the management of real estates owned by legal persons of churches and other religious associations in Poland and the indication of the approaches to such matters adopted in other exemplary countries of the world. The research method was a case study based on analyses including literature of the subject and legal acts regulating the issues - both concerning state and canonical law, and good practices in this matter. The intention is to indicate the relevant applicable rules, specify the existing problems and draw attention 
to the complexity of the rules. Due to the above-mentioned multitude of provisions and regulations in this regard, the author shall focus, above all, on selected examples concerning - in particular - the Catholic Church.

\subsection{Administration of the goods}

The supreme administrator of all ecclesiastical goods is the Roman Pontiff - the Pope. A metropolis is presided over by a Metropolitan, who is archbishop in his own diocese. In civil, administrative and criminal affairs, the diocese is represented by the diocesan bishop, whereas a parish is represented by the parish priest. The management of ecclesiastical goods owned by public legal persons involves possession thereof and execution of the vested rights. Its purpose is to preserve the goods by protecting them against loss, increasing their efficiency and allocating the ecclesiastical goods according to their intended purpose. Regardless of the relevant legal norms applicable in Poland, the Church may create its own regulations. KALETA (2017) highlights the fact that a crucial role in the administration of ecclesiastical goods is played by the management criteria developed by the Congregation for Bishops in the Directory of Apostolorum Successores, which include: the criterion of pastoral and technical competence, the participation criterion, the asceticism criterion, the apostolic criterion and the criterion of a good father of a family.

It is possible to distinguish ordinary administration which encompasses regular and repetitive activities that pose no risk of deterioration to the ownership status and that require no authorization from major superiors. Such activities include, amongst others, ordinary actions aimed at maintaining sacred and church buildings in proper technical and working condition, protecting them against loss or deterioration, insurance, storage of documents and proofs certifying the Church's or a given institution's rights to the property, etc. The administrator's task is also to maintain and update the inventory containing information about such aspects as the status of immovable property. The phenomena observed on real estate markets indicate that the success of structural transformations and the development of property information systems are determined mainly by the quality and availability of information about real estate (DAWIDOWICZ, ŹRÓBEK 2017). Access to reliable data or information, however, is difficult nowadays, not so much because of the lack of access to them, but due to excessive amounts of such data (so-called information noise) and difficulties in the proper selection of the right type of data (RENIGIER-BIŁOZOR 2017). The accuracy of information from public records, i.e. the register of land and buildings, obtained by entities managing property has a direct impact on the correctness of the conducted processes of land management (KWARTNIK-PRUC 2015). Therefore, any entry into the cadastral database can only be made based on relevant documents (PUNIACH, BIEDA et al. 2018). In literature, it is repeatedly highlighted as necessary for ecclesiastical goods to have established land and mortgage registers and updated entries in the land and property register (cadastre). The key role in providing designation of properties (area of parcels, location of boundaries, land use, etc.) for the needs of their specification is played by surveying and photogrammetry. Nowadays, many works in the fields of contemporary geodesy and cartography concern the use of digital maps or satellite images (PRZEGON, BACIOR, SOBOLEWSKA-MIKULSKA 2017).

The activities encompassing acts of extraordinary administration, on the other hand, are specified by the episcopal conference of a given country. There are detailed instructions concerning the administration of ecclesiastical goods (in the form of a manual, directory, in diocesan synods), intended to clarify the relevant rules. Acts of extraordinary administration include, amongst others, acceptance or rejection of an inheritance or donation, waiver of any property rights, acquisition of real estate, sale, exchange, donation, establishment of land, transfer or personal easement, lease or rental of ecclesiastical real estates, commencement of any investments - maintenance, construction works, etc. Moreover, the above-mentioned activities should also include taking litigious actions before courts on behalf of church legal persons, acknowledging claims, resignations from pursuing claims, entering into settlements, submitting a request for entry into the Register of Historical Monuments or a request for removal from it. Their typical feature is that they are not undertaken on a regular basis and exert an impact on the asset-related condition of a church legal person, which - in a number of cases requires the consent of relevant entities indicated in the internal law. For instance, the decisions concerning the scope of real property management on behalf of a parish are taken by the parish priest, but a number of such decisions require the consent of an ordinary or the diocesan bishop. In the case of goods belonging to dioceses, the diocese bishop being the sole administrator of the diocese should, 
prior to carrying out administration acts of major importance, consult the finance committee and the college of consultors (consent from the absolute majority of the college or team is required). Furthermore, institutes, provinces and religious houses are subject to limitations arising from the specificity of a given institute. They are also obliged to avoid all appearance of luxury, excessive gain and the accumulation of goods. Religious institutes of diocesan right, even though they remain under the supervision of the diocesan bishop, are a public, rather than an ecclesiastical legal person, and the management of their goods is subject to its own norms. They have their representatives, known as the guardians of legal persons. Meanwhile, religious institutes of pontifical right enjoy autonomy in terms of goods management, and their power is also referred to as the power of jurisdiction.

It is worth pointing out that, pursuant to Article 55, Section 4 of the Act of 17 May 1989 on the relations between the State and the Catholic Church in the Republic of Poland, legal persons of the church are exempt from taxes and fees for the commune and municipal funds on real estate or its part that are owned or used by these persons under a different legal title for non-residential purposes, with the exception of the part occupied for conducting economic activities. Moreover, there are cases when such exemption also concerns real estates or their parts earmarked for residential purposes of clerics and members of religious institutes (for example if they are listed in the Register of Historical Monuments, constitute dormitories at schools and seminaries, contemplative religious houses, formation houses of orders and houses for priest and nun retirees, etc.

Interestingly, sacred structures are the second most numerous group amongst all the immovable heritage objects in Poland and, according to the data from the Catholic Church Institute of Statistics, in 2011 the Catholic parishes in Poland administered as many as 33,466 immovable heritage objects (GUS 2014). On the other hand, the Greek Catholic Church possessed 61 heritage objects within the area of the diocese of Przemyśl and Warsaw, and 13 such objects within the area of the diocese of Wrocław and Gdańsk. In view of the above, in the management process of ecclesiastical goods of historic importance, performance of many activities on real properties located in these areas is strongly restricted by a number of legal regulations whose aim is to protect historical buildings and monuments (MUCZYŃSKI et al. 2015)., seeing as how, in many cases, they constitute monumental areas, great attention is paid in Poland to preserve the primary character of such places (BIEDA, PARZYCH 2013). The group of immovable sacred objects includes both the structures directly related to a religious cult (churches/temples, cloisters, belfries, chapels, cemetery chapels, mortuaries, roadside chapels, shrines and crosses), those not directly related (cloister buildings, church bell towers), as well as secular structures regained as former church properties or acquired or taken over for handling church administration (parish houses, rectories, diocesan buildings). The historical monuments owned by churches and religious associations are the largest group of heritage objects that require no renovation works $(14 \%)$ or require merely minor repairs $(48 \%)$, as well as the smallest group of heritage objects that require complete refurbishment (13\%) (GUS 2014). Ecclesiastical entities undertake works related to the maintenance and restoration of sacred heritage objects, often obtaining subsidies both in Poland and from the European funds. In other countries of the world, the protection of such monuments also constitutes strategic action, though the rules regarding it differ. In the USA alone, local historical preservation ordinances can differ considerably from one jurisdiction to another, so the interplay between federal and local laws is not uniform (ASABERE, HUFFMAN 1995).

\subsection{Alienation and acquisition of goods}

The legal personality of ecclesiastical and religious legal persons constitutes the basis for participation in civil law transactions. In the case of legal persons of the Catholic Church, such participation is subject not only to the regulations of the Polish (secular) law, but also to the canon law, whose primary source is the Code of Canon Law in force since 1983. As indicated by TOMKIEWICZ (2013), a resolution of the Supreme Court dated 19 December 2008 has shaped the jurisprudence concerning the effectiveness of canon law in the state legal order. However, controversies pertaining to the legitimacy of observing canon law in legal transactions remain very much alive. As mentioned before, the Church and its legal persons have the right to acquire immovable properties, including by way of a contract of sale, a life estate deed, a contract of donation, a last will and testament, etc. An interesting issue is the aspect of acquiring agricultural real estates by churches and religious associations in Poland. Due to the changes in the Act of 11 April 2003 on structuring the agrarian system, complications and restrictions in the rules of turnover of acquiring agricultural properties in Poland can be observed. The above mentioned provisions introduced the principle that the acquirer of 
agricultural property can be, with few exceptions, only an individual farmer possessing a farm, agricultural qualifications and residing in the commune for at least five years. The area of the acquired agricultural property, however, together with the area of the agricultural properties included in the acquirer's family farm cannot exceed the area of 300 ha of cultivated land (CIENCIAEA 2017). Meanwhile, one of the exceptions to this rule is the acquisition of agricultural property by the legal persons operating under the provisions on the relations between the State and the Catholic Church in the Republic of Poland, on the relations between the State and other churches and religious associations as well as on the guarantees of freedom of conscience and religion (e.g. donations to the Church or a religious association from a natural person).

The term which appears in canon law and is closely related to the administration of real estates owned by ecclesiastical legal persons of, amongst others, the Catholic Church is the alienation of goods. This term shall be understood to mean the transfer of right to real estate (donation, sale, exchange, etc.), the encumbrance of ecclesiastical property with easement (e.g. contractual easement of transfer) or the right of use. This can take place when it is justified by legitimate grounds, permission has been obtained from competent authorities, any previously alienated goods are identified, competent valuation of the subject of alienation is ensured, and the price obtained from the transaction is not lower than that indicated in the surveyors' valuation (unless such alienation is permitted by the entity granting permission for alienation) and when other precautionary measures indicated by competent authorities are observed. What is interesting, in the first centuries of the Church, ecclesiastical goods were considered sacred objects, so their alienation was prohibited, whereas, under the 1917 Code, alienation was acknowledged as a kind of extraordinary administration. Currently, while undertaking the act of alienation and transaction, account must be taken of the minimum amount established by the episcopal conference and the maximum amount of alienation indicated by the Holy See for a given region. In the event where the value of alienation exceeds the amount specified by the episcopal conference, it is necessary to obtain permission of the competent power and consent from all consultative bodies, namely the diocesan council for economic affairs and the college of consultors. Where the maximum alienation amount is exceeded or the goods have been donated to the Church as a result of a vow or are of a significant artistic or historical value, the consent of the Holy See is required in addition to the consent of the superior. Moreover, a prerequisite for alienation to be lawful is that valuation be performed by two independent appraisers (there are no canonical requirements as to who can be an appraiser). It is indicated in the literature that the correct approach is evaluation based on the market value for the current state. The results of the conducted research, however, show that money is not always a sufficient means to indemnification (HOLTSLAG-BROEKHOF, VAN MARWIJK et al. 2016). The authors emphasize that acquisition has an essential element of injustice that cannot be avoided by a good process or a just compensation fee. As indicated by TOMKIEWICZ (2013), the requirements for valuation to be performed refer not merely to the sale of property but also to the exchange of goods. It is also a rule that, when a request is made to alienate goods which are divisible, the request must state what parts have already been alienated. Similarly, when various goods of the same entity are alienated, it is necessary to add up their values and, based on their aggregate amount, specify the competent entity to grant consent to.

\subsection{Nationalization, repossession and seeking actions in court}

Analyzing the historical aspect, it is crucial to underline that it was not uncommon for church property to experience turbulences on the international scene. In the Czech Republic, for instance, the property of religious associations, in particular the Catholic Church, was greatly reduced by agricultural reforms in 1919 and 1948. According to NÉMEC (2010), property rights were later often seized and, in 1949, a repressive and anti-church statute concerning the economic security of churches and other religious associations was adopted. In Poland, in the years 1944-1962, there was a series of legal acts that nationalized almost all ecclesiastical real estates: agricultural, forestry, urban and industrial, and even those belonging to foundations and associations. One of the legal regulations that resulted in a considerable limitation of land property areas owned by religious associations was the Act of 20 March 1950 on the takeover of mortmain property, entrusting farmland to parish priests and the creation of the Church Fund. Pursuant to Article 4, Section 2, parish priests received guarantees for their land properties of up to $50 \mathrm{ha}$, and in the Poznań, Pomerania and Silesia province - up to 100 ha. 
With reference to former German areas, this had already happened before on the basis of the decree of 6 September 1946 on the agrarian system and settlement in the Regained Territories and the former Free City of Gdańsk. An attempt to determine the scale of nationalization for real estates owned by legal persons of the Catholic Church in Poland was undertaken by WALENCIK (2013). In the author's opinion, legal persons of the Catholic Church in the territory of Poland, from 1939, owned at least 380,700 ha of land, yet lost all their real estate in the eastern borderlands of the Second Polish Republic (approximately 208,921.5 ha), approximately 144,738.2781 ha in the so-called old lands, as well as almost all the real estate in the northern and western territories of Poland (approximately 31,734 ha).

The asset-related situation of the Catholic Church was not regulated until the entry into force of the Act of 17 May 1989 on the relations between the State and the Catholic Church in the Republic of Poland. Then, pursuant to Article 60, real estates or their parts which - upon the entry into force of the Act - remained in the possession of church legal persons, became their property by virtue of law if such real estates constituted the property of dioceses, parishes, cloisters, were subject to taking over by the state under the Act of 20 March 1950 on the takeover of mortmain property, entrusting farm land to parish priests and the creation of the Church Fund, yet were left, leased or transferred to church legal persons, included cemeteries or sacred objects along with accompanying buildings (from the moment of entry into force of the Act of 11 October 1991 amending the Act on the relations between the State and the Catholic Church in the Republic of Poland), etc. Moreover, the above-mentioned act specified the conditions for applying for the restitution of nationalized real estates or their parts, granting replacement properties or financial compensations. The transfer of ownership was ascertained through a decision of a provincial governor competent for the territory in question. In the years 1990-2011, the real estates of church legal persons were subject to repossession by way of regulatory proceedings conducted by the Property Commission. According to WALENCIK (2013), as a result of the activities by the above-mentioned Commission, legal persons of the Catholic Church were returned or transferred real estates with the area of $65,705.2221$ ha, while - by virtue of lawfully concluded court proceedings - real estates with the area of 29.7674 ha. The author believes that real estates covering an area of 62,357.5844 ha were not restored to legal persons of the Catholic Church.

In 1991-2004, the legislator also regulated - in the form of separate laws - the legal status of a series of other churches and religious associations in Poland, guaranteeing them the right to reprivatization. A system of ecclesiastical reprivatization was developed to regulate the asset-related issues between the state and churches and their legal persons that have raised claims on the terms and in the manner defined in the acts. Each of the churches and religious associations had its own procedure, regulated by means of separate laws, for examining the requests for restitution of the property taken away.

Restitution of property of Jewish religious communities, for instance, has recently become possible in accordance with Article 29, Section 1 of the Act of 20 February 1997 on the relations between the State and Jewish religious communities. Real estates or their parts remaining in the date of the enactment of that legal act in the possession of Jewish commonalties and religious congregations became their property under the provisions of law (CIENCIAŁA, FLOREK-PASZKOWSKI 2016) (by way of a decision of the locally competent governor). What is more, on the basis of the article 30, it is possible to initiate the proceedings aiming to transfer, to the Jewish commonalties and religious congregations, the ownership of real estates or their parts that were taken over by the State, and which, on the 1 September 1939, were the properties of Jewish religious communities or other religious Jewish legal persons if there were Jewish cemeteries and synagogues on them that day or buildings formerly constituting the seat of the Jewish religious communities and the buildings formerly serving religious purposes, educational activities and educational and charitable care located in them on the date of the enactment of the legal act. The ascertainment of the acquirement of real estates was formerly done by a regulatory commission for the affairs of Jewish communities, but it might involve the transfer of their parts, the granting of the suitable replacement property, or the granting of compensation. It is widely known that the religious communities used to gather considerable assets - synagogues, prayer houses, cemeteries, etc. According to TYCH, ADAMCZYK-GRABOWSKIEJ et al. (2011) the pre-war religious communities had, amongst other things, about 2,000-2,500 cemeteries (including approximately $60 \%$ within the current area of the country and about 200 in the western connected areas) and a total of about 10,000 synagogues and prayer houses (about 60\% within the current area of the country). According to TYCH, ADAMCZYK-GRABOWSKIEJ et al. (2011), by 11 May, 2002 - designated by the act as the deadline for submission of applications for regulatory proceedings, there had been about 5,504 applications filed. About $26 \%$ of them were resolved by October 2008, half of them positively. 
On the other hand, ownership disputes concerning properties of the Orthodox Church were initially settled only by the head of the Office of the Council of Ministers and it was not until 20 May 1999 that proceedings started to be held before the Regulatory Commission of the Polish Autocephalous Orthodox Church. BENDZA (2009) indicated that, through administrative proceedings, the particular legal persons of the Church received 866 ha of agricultural and forestry lands, 32 cemeteries, 1 chapel and 4 developed properties, and 61 cases were referred to the Regulatory Commission. The Author noted that the Regulatory Commission of the Polish Autocephalous Orthodox Church, as of 31 March 2008, received 515 applications (the Catholic Property Commission 3,063 applications as of 31 December 2007 and the Regulatory Commission on Jewish Religious Communities - 5,544); 217 proceedings were completed with comprehensive settlement, 57 - with partial settlement, 3 - with a judgment on damages, 11 - with a judgement on transfer or provision of real estate. According to BENDZA (2009), the legal act specifying the legal status of the Catholic Church in Poland dated 17 May 1989 was more advantageous in terms of the repossession than the procedure adopted in the Orthodox law.

After abolishing the Property Commission before which proceedings concerning real estate repossession were carried out, church legal persons who failed to submit requests to the Commission, submitted such requests after the deadline or the requests concerned only some of their claims, may assert their rights through administrative or judicial proceedings. It is the court that rules on the restitution of real estate taken over by the State Treasury without a legal basis, in a situation where no administrative decision has been issued. Furthermore, in one of its rulings, the Supreme Court stated that church legal persons may claim before a court - after an ineffective conclusion of regulatory proceedings - both that their nationalized real estates be restituted and that the title to the real estates be transferred to them (BENDZA 2009). However, as had already been mentioned, taking litigious actions before courts on behalf of church legal persons, acknowledging claims, resignations from pursuing claims, entering into settlements, etc. exceed the acts of ordinary administration and fall within the scope of acts of extraordinary administration. As highlighted by KALETA (2017), disputes concerning church property may pose a serious risk that the property status will be deteriorated and a given parish exposed to costs. The Author points to the concern that initiation of judicial proceedings in a state court may contribute to unnecessary escalation or publicising of the case on media and social forums, and may even generate similar processes against other church legal persons. It is preferable, therefore, to take measures aimed at its preventing (e.g. through amicable settlement of disputes). Disputed cases, except for small claims, require the consent of an ordinary, who issues a relevant document after obtaining consent from the diocesan finance committee and the college of consultors.

\section{Empirical results}

The table below presents the results of the SWOT analysis prepared for the methods of management applied in the case of the real estates belonging to churches and religious associations in Poland. According to DOBAK (2002), to create a development strategy, at every level of detail, the first stage is the diagnosis of the state, the basic technique of which is SWOT analysis. DAWIDOWICZ, KLIMACH, SZPARA (2017) indicate that the SWOT analytical technique involves the segregation of case information into four groups:

- S (Strengths) - the advantages of the analyzed object,

- W (Weaknesses) - defects of the analyzed object,

- O (Opportunities) - everything that provides the chance of positive change for an analyzed object,

- $\mathrm{T}$ (Threats) - everything that creates the risk of unfavorable changes for an analyzed object.

SWOT provides the basic outline within which to perform an analysis of the decision situation (POLAT, ALKAN, SÜRMENELI 2017). BIEDA, BRZOZOWSKA (2017) perceive the method as the one used for ordering and analyzing heuristic information.

\begin{tabular}{|c|c|}
\hline STRENGTHS & WEAKNESSES \\
\hline $\begin{array}{l}\text { - civil law transactions subject both to the regulations of the } \\
\text { Polish (secular) law and canon law, } \\
\text { - detailed instructions concerning the administration of } \\
\text { goods (manuals, directories, diocesan synods), } \\
\text { management criteria developed by the Congregation for }\end{array}$ & $\begin{array}{l}\text { - discrepancies in the interpretation } \\
\text { of the legitimacy of respecting } \\
\text { the canon law while performing legal acts } \\
\text { in the state order, } \\
\text { - separate legal acts specifying the legal }\end{array}$ \\
\hline
\end{tabular}




\section{Bishops,}

- specification of the acts of extraordinary administration requiring the permission of the competent power and consent from all consultative bodies,

- establishing the obligatory minimum amount of alienation and transaction (by the episcopal conference) and the maximum amount of alienation (by the Holy See for a given region),

- valuation of a property, in case of alienation, performed by two independent appraisers.

OPORTUNITIES

- in most cases exemptions from taxes and fees for the commune and municipal funds on real estates for non-residential purposes (sometimes also properties earmarked for residential purposes of clerics and members of religious institutes),

- great attention paid to preservation of the goods of historic importance, the management process strongly restricted by a number of legal regulations in such cases,

- possibilities of repossession - return or transfer of real estates through administrative or judicial proceedings,

- possibility of the acquisition of agricultural property as an exception from the rule that the acquirer of agricultural property can be only an individual farmer fulfilling the specified conditions,

- subsidies for undertaking works related to the maintenance and restoration of sacred heritage objects, including the ones from the European funds.

Source: own work.

\section{Discussion and conclusions}

The management of real estates owned by legal persons of churches and other religious associations, due to their multitude and the multiplicity of applicable rules and regulations, is a very extensive issue closely related to the specificity as well as the economic conditions of the particular countries. Churches apply separate solutions concerning property management, which are specific to each of them and contain various levels of detail.

In Poland, the management of ecclesiastical real estates is subject both to the regulations of the Polish (secular) law and to canon law. There are detailed instructions concerning the administration of goods (manuals, directories, diocesan synods), management criteria developed by the Congregation for Bishops, established minimum and maximum amount of alienation, etc. Specified acts of extraordinary administration require the permission of the competent power and consent from consultative bodies. Their overarching objective is the protection of the goods possessed.

Over the years, limitation of property areas due to nationalizing legal acts has constituted the most serious threat to the ecclesiastical goods. Moreover, separate legal acts specifying the legal status of churches and their own procedures for examining the requests for the restitution of a property in some cases have been considered as not equally fair. Nowadays, as many sacred objects are historical monuments; there are a lot of subsidies for undertaking works related to their maintenance and restoration. Moreover, there are possibilities of repossession of previously nationalized real estates through administrative or judicial proceedings.

As a result, the administration of ecclesiastical goods is an important and topical issue, and its functioning on the basis of two legal systems requires the administrator to be knowledgeable in both state law and canon law. Managerial activities require prudence in making decisions not to cause the infringement of a church legal person's property status or litigations in this regard.

\section{References}

AsAbere P., HuffMAn F., 1995, Real Estate Values and Historic Designation. 
CODEX IURIS CANONICI auctoritate Ioannis Pauli PP. II promulgatus (25.01.1983), AAS 75 (1983), part II, s. 1-317; Kodeks Prawa Kanonicznego, przektad polski zatwierdzony przez Konferencję Episkopatu, Poznań 1984 (The Code of Canon Law, Polish translation approved by the Episcopal Conference).

Beal John P., 2016, Protecting the Patrimosny of the Poor: Securing Civil Recognition of Church Property in the United States, The Temporal Goods of the Church. Selectes Issues, ISBN 978-83-946990-0-0, Deanprint Ltd, London.

BENDZA W., 2009, Regulacja kościelnych spraw majątkowych na przykładzie Kościoła prawosławnego w Polsce, ISBN 978-83-7601-924-6, Oficyna a Wolters Kluwer business Warszawa, (The regulation of church property matters on the example of the Orthodox Church in Poland).

BiEDA A., BRZOZOWSKA A., 2017, Analiza SWOT/TOWS jako metoda określania kierunków rozwoju przestrzennego, Acta Sci. Pol., Administratio Locorum, Vol. 16(3), 151-160 (Swot/Tows analysis as a method of determining spatial development directions).

BiEDA A., PARZYCH P., 2013, Development of spatial politics of monumental towns based on Krakow example, International Multidisciplinary Scientific GeoConference: SGEM: Surveying Geology \& mining Ecology Management, Vol. 2, Sofia, Bulgaria.

CiENCIAEA A., 2017, The issue of the legal and surveying division of agricultural land on selected examples in Poland and on the international stage.Geographic Information Systems Conference And Exhibition. Gis Odyssey, Perugia, Italy.

CiENCIAEA A., FLOREK-PASZKOWSKI R., 2016, Abandoned properties in the processes of real estate management in Poland, ISBN: 978-953-6129-55-3, Geographic Information Systems Conference And Exhibition - Gis Odyssey, Perugia, Italy.

DaWidowicz A., Klimach A., SzPARA A. Management of Seaport Real Estate Stock in Relation: PortMarine City, Geomatics and Environmental Engineering, Vol. 11(4), 35-50, 2017.

DAWIDOWICZ A., ŹRÓBEK R., 2017, Land administration system for sustainable development - case study of Poland, Real Estate Management and Valuation, Vol. 25, Issue 1, Olsztyn.

Dekret z 6 września 1946 r. o ustroju rolnym i osadnictwie na obszarze Ziem Odzyskanych i byłego Wolnego Miasta Gdanska, Dz.U. 1946 nr 13, poz. 87 (Decree of 6 September 1946 on the agricultural system and settlement in the area of Regained Territories and the former Free City of Gdansk, Journal of Laws, 1946, No.49, item 279).

DOBAK P., 2002, Środowiskowa problematyka geologiczno-inżynierska w planowaniu przestrzennym, Przegląd Geologiczny 50(10-02), 924-928, (Environmental and geological-engineering analysis in town and country planning).

GUS. Rocznik statystyczny. Kościót Katolicki w Polsce 1991-2011, Główny Urząd Statystyczny, Warszawa, 2014 (Statistical yearbook. Catholic Church in Poland 1991-2011, Central Statistical Office).

GUS. Notatka informacyjna opracowana wspólnie z Instytutem Statystyki Kościoła Katolickiego SAC. Struktura administracyjna Kościoła katolickiego w Polsce i podstawowe statystyki, Główny Urząd Statystyczy, Warszawa, 2017 (Information note prepared jointly with the Institute of Statistics of the Catholic Church SAC. The administrative structure of the Catholic Church in Poland and basic statistics, Central Statistical Office).

HeARING S., 2016, The financing of the Catholic Church in Germany on the Current Situation and Possible Tendencies of Future Developments, The Temporal Goods of the Church. Selectes Issues, ISBN 978-83946990-0-0, Deanprint Ltd, London.

Holtslag-Broekhof S.M., VAn MARwijK R., Beunen R., Wiskerke J.S.C., 2016, Perceived justice of Public Land Acquisition, Journal of Agricultural and Environmental Ethics. Vol.29 (2).

KAlETA P., 2017, Prawne aspekty zarzadzania dobrami kościelnymi, ISBN 978-83-8061-343-0, Wydawnictwo KUL, Lublin (Legal aspects of church property management).

KALETA P., 2012, Zadania zarzadcy majątku kościelnego w kodeksie prawa kanonicznego z 1983 r. i w polskich synodach djecezjalnych, ISBN 978-83-7270-994-3, Polihymnia, Lublin, (Tasks of the administrator of ecclesiastical property in the canon law code of 1983 and in Polish diasporal synods).

KlimaCH A., DAWIDOWICZ A., ŹRÓBEK R., 2018, The Polish land administration system supporting good governance, Land Use Policy, Vol. 79, 547 - 555.

KWARTNIK-Pruc A., 2015, Possibilities Of Using Innovative Sources Of Information On Real Estate In The Spatial Data Collection Process, Real Estate Management and Valuation 23 (1), 103-113.

MALESA W., WAWRZASZEK A., 2014, Rejestr wyznaniowych osób prawnych - wybrane zagadnienia na przykładzie jednostek Kościoła Katolickiego, Studia z prawa wyznaniowego, Vol. 17, (The register of 
religious legal entities - selected questions on the example of units of the Catholic Church).

MucZYŃSKI A., ŹRÓbeK R. FOrYŚ I., KeMPA O., BiedA A. (...), 2015, Real Estate Management. Spatial analysis supported by GIS tools, ISBN 978-953-6129-46-1, Nacionalna knjižnica, Zagreb, Croatia.

NÉMEC D., 2010, Projekt ustawy o majątku i finansowaniu kościołów i innych zwiazków wyznaniowych w Republice Czeskiej $z 2008$ r. w świetle obowiazujacych umów konkordatowych $z$ państwami postkomunistycznymi, Studia z prawa wyznaniowego, Vol. 13, 2010 (A Proposal of the 2008 Act on the Property and Financing of Churches and Religious Denominations in the Czech Republic in the Light of the Binding Concordat Agreements with Post-Communist States).

PaAsch J., Paulsson J., Navratil G., Vučić N., Kitsakis D., Karabin M., El-MeKaWy M., 2016, Building a modern cadastre: legal issues in describing real property in 3D, Geodetski Vestnik, Vol. 60, No. 2.

POlAT Z. A., ALKAN M., SÜRMENELI H.G., 2017, Determining strategies for the cadastre 2034 vision using an AHP-Based SWOT analysis: A case study for the turkish cadastral and land administration system, Land Use Policy, Vol. 67, 151-166.

PRZEGON W., BACIOR S., SOBOLEWSKA-MIKULSKA K., 2017, Cartographic analysis of transformations of the spatial structure of lands of Podgórze in Kraków in Poland in the period of 1847-2016, Geodetski Vestnik, Vol. 61 No. 2.

Puniach E., Bieda A., ĆWiąKąa P., KWARTNiK-PRuc A., PARZYCh P., 2018, Use of unmanned aerial vehicles (UAVs) for updating farmland cadastral data in areas subject to landslides, ISPRS International Journal of Geo-Information, Vol. 7 (Issue 8).

RENIGIER-BIŁOZOR M., 2017, Modern classification system of real estate markets, Geodetski Vestnik, Vol. 61 No. 3, 2017.

SLACK P., 2016, Financing of the mission of the Catholic Church in Australia. Strengths and Challenges. The Temporal Goods of the Church. Selectes Issues, ISBN 978-83-946990-0-0, Deanprint Ltd, London.

SOBOLEWSKA-MiKULSKA K., 2014, Gospodarka nieruchomościami i kataster. Wybrane problemy, Oficyna Wydawnicza PW, Warsaw, 2014 (Real estate management and cadastre. Selected problems).

TOMKIEWICZ M., 2013, Obrót majątkiem kościota rzymskokatolickiego w Polsce, ISBN: 978-83-6412-903-2, Wydział Teologii UWM, Olsztyn, (Trade of the property of the Roman Catholic church in Poland).

TYCH F., ADAMCZYK-GRABOWSKA M. et al., 2011, Następstwa zagłady Żydów. Polska 1944-2010, 978-83227-3263-2, UMCS Publishing Company, Lublin, (The consequences of the holocaust of Jews. Poland 1944-2010).

Uchwała Sądu Najwyższego z 19 grudnia 2008 r., III CZP 122/08 (Resolution of the Supreme Court of December 19, 2008, III CZP 122/08).

Ustawa z dnia 11 kwietnia 2003 r. o ksztattowaniu ustroju rolnego, Dz.U. 2003 nr 64, poz. 592 (Act of 11 April 2003 on shaping the agricultural system, Journal of Laws, 2003, No. 64, item 592).

Ustawa z dnia 20 lutego 1997 r. o stosunku Państwa do gmin wyznaniowych żydowskich w Rzeczypospolitej Polskiej, Dz.U. 1997 nr 41, poz. 251 (Act of 20 February 1997 on the relation of the state to Jewish religious communities, Journal of Laws of 1997, No.41, item 251).

Ustawa z dnia 11 października 1991 r. o zmianie ustawy o stosunku Państwa do Kościoła Katolickiego w Rzeczpospolitej Polskiej, Dz.U. 1991 nr 107, poz. 459 (Act of 11 October 1991 amending the act on the relation of the State to the Catholic Church in the Republic of Poland, Journal of Laws, 1991, No.107, item 459).

Ustawa z dnia 4 lipca 1991 r. o stosunku Państwa do Polskiego Autokefalicznego Kościoła Prawostawnego, Dz.U. $1991 \mathrm{nr}$ 66, poz. 287 (Act of 4 July 1991 on the relation of the State to relationship to the Polish Autocephalous Orthodox Church, Journal of Laws, 1991, No.66, item 287).

Ustawa z dnia 17 maja 1989 r. o stosunku Państwa do Kościoła Katolickiego w Rzeczypospolitej Polskiej, Dz.U. 1989 nr 29, poz. 154 (Act of 17 May 1989 on the relation of the state to the Catholic Church in the Republic of Poland, Journal of Laws, 1989, No.29, item 154).

Ustawa z 20 marca 1950 r. o przejęciu przez państwo dóbr martwej ręki, Dz.U. 1950 nr 9, poz. 87 (Act of 20 March 1950 on taking over the property of the dead hand, guaranteeing priests ownership of farms and establishing the Church Fund, Journal of Laws, 1950, No.9, item 87).

WALENCIK D., 2013, Nieruchomości Kościota katolickiego w Polsce w latach 1918-2012, ISBN: 978-83-7593191-4, Drukarnia Archidiecezjalna w Katowicach, Katowice, (Real Estates of the Catholic Church in Poland in 1918-2012). 